Ataman A., Çok F. \& Şener T. (2012). Understanding civic engagement among young Roma people in Turkey. Human Affairs, 22(3), 419-433.

\title{
Understanding Civic Engagement Among Young Roma and Young Turkish People in Turkey ${ }^{1}$ \\ Ayşenur Ataman, Figen Çok, Tülin Şener ${ }^{2}$
}

\begin{abstract}
Although a number of aspects of earlier experiences correlate with later civic engagement (Sherrod, 2007), the role of different factors in driving the level of young people's engagement is not clearly understood. This qualitative study set out to understand those factors in Turkey. 8 focus groups were conducted with 55 young Roma and Turkish people, with different groups being conducted according to participants' ethnicity, gender and age (16-18 year olds vs. 20-26 year olds). Analysis revealed specific themes in terms of the political and civic engagement of different sub-groups. However, almost all participants expressed that they did not have enough information about their rights and obligations as citizens. They also identified the different barriers which they perceived as impeding their political involvement and participation.
\end{abstract}

\section{Introduction}

In recent years, the civic and political engagement of young people has been the focus of much research. This focus is due to concerns about growing levels of political apathy and disengagement. Research indicates that political participation measured with conventional indicators has declined precipitously among younger generations in recent decades (Galston, 2001; Skocpol, 2003; Watts and Flanagan, 2007). We believe that age, gender and ethnicity are essential to investigate the

1 The research reported in this paper was supported by a grant received from the European Commission 7th Framework Programme, FP7-SSH-2007-1, Grant Agreement no: 225282, Processes Influencing Democratic Ownership and Participation (PIDOP) awarded to the University of Surrey (UK), University of Liège (Belgium), Masaryk University (Czech Republic), University of Jena (Germany), University of Bologna (Italy), University of Porto (Portugal), Örebro University (Sweden), Ankara University (Turkey) and Queen's University Belfast (UK).

2 Aysenur Ataman is PhD candidate in City University of New York, Ass. Prof. Tulin Sener is from Ankara University, Faculty of Educational Sciences and Prof. Dr. Figen Çok is from Başkent University, Faculty of Education. 
processes underlying political disengagement. In this paper, we focus on perceptions of citizenship and patterns of civic and political participation among young Roma people and Turks. The comparison of civic and political participation among young Roma people as a marginalized group and Turks as the majority group in Turkey can help to expand our understanding of the factors that are responsible for civic and political disengagement.

Most of the studies that have examined civic engagement and participation have considered the mechanisms by which citizens may benefit from involvement. As the definition of citizenship emphasizes, engagement and participation are important not only at an individual level, but also at a social level. For instance, an active involvement that requires interaction with others allows citizens to develop personal and social capacities and thus to increase interpersonal trust and tolerance (Stewart and Weinstein, 1997). While sharing a common framework, they experience different social and cultural structures, and learn to acknowledge other people's points of view (Arendt, 1958). In this change building process, it is important to know that the ideas that emerge from other citizens are meaningful from the point of view of participants so they can accept the challenge of working together for the common good (Putnam, 1993; Menezes, 2003). As a result, citizens who are engaged in society feel that they are authorized to regulate the structures they are a part of (Zimmerman, 1995) and this feeling contributes to a common sense of community (De Piccoli, Colombo and Mosso, 2002).

On the other hand, it is essential to understand the engagement of not only adults but also young people. Flanagan and Faison (2001) distinguish the "civic" from the "political". They argue that "political" has come to relate mainly to the polity and to the state or government, while "civic" has a broader meaning. The civic sphere provides an arena for youth participation, in which youth can function as "agents of change in building the asset-promoting qualities of communities and societies" (Sherrod, 2007, p.63). Regardless of their ethnicity, immigrant status, social class, and gender, youth should be able to have access to different sources in order to practice actions regarding with civic engagement and participation. Obviously, the perceptions and the understandings related with the action may change but the result of early experience will persist into adulthood (Flanagan and Sherrod, 1998). 
However, studies over the last decade, and policy studies in this area, have shown that people are participating less in many kinds of shared activities, from trade unions and political parties and other sorts of voluntary membership organizations, while voting rates are also dropping (IEA Civic Education Study, 1999). Although the levels of social and political participation show variations according to national and life context (Skocpol and Fiorina, 1999), young people, women and ethnic minorities are specific groups at risk of social and political disengagement. Unconventional forms of participation such as participating in demonstrations, internet activism or acts of civil disobedience among these groups have increasing potential and could have dramatic effects in the societies concerned (Barnes and Kaase, 1979).

In order to understand the role that age, gender and ethnicity play in people's civic engagement, and to compare perceptions across different life contexts, this paper reports the findings of focus groups that were carried out with young people in Turkey between April and June 2010 within the scope of the PIDOP project. This paper reports findings from the focus groups that were carried out with young people from two sub-groups: majority Turks and minority Roma.

\section{Young Turks}

There are almost 18 million young people living in Turkey aged between 14 and 29, representing $24 \%$ of the total population in Turkey (Turkish Statistical Institute, 2010). However, despite this large youth population, Turkey lacks a national youth policy that might lead to active young citizens. As the National Human Development Report entitled "Youth in Turkey" (UNDP, 2008) points out, there is an urgent need within Turkey for a comprehensive policy on youth participation based on human rights, and for the development of the necessary legal framework and the construction of suitable local and national mechanisms to ensure youth participation.

On the other hand, although young Turks still have some vulnerability due to their age, within the scope of this study it is important to mention the issues of religious affiliation, level of education, household income and poverty. When we consider young people who are exposed to social exclusion because of their age, the literature on the subject emphasises poor and uneducated people and people outside 
the dominant ethnicity and culture (Adaman and Keyder, 2006). Therefore, it is important to emphasize that young Turks have a better educational, occupational and income level, alongside better parental education and income, in comparison with young Roma people. Young Turks also hold Islam as their main dominant religion, as it is for most of the adult population in Turkey.

\section{Roma people in Turkey}

There is no reference in the Constitution to the word 'minority' and there is no legislative framework for ethnic or religious groups in Turkey, either directly through laws granting minority rights or indirectly through anti-discrimination law (Minority Rights Group International, 2007). According to the Constitution, the concept of citizenship does not include any reference to ethnic and/or religious identity. In that sense, legally, all citizens, without reference to their ethnic or religious backgrounds, have equal rights and obligations. The number of individuals belonging to various cultural and religious groups is unknown due to the fact that the national censuses do not include questions on ethnic and religious identities. At the foundation of the Turkish Republic, the only protection for minorities was set out in 1923 in the Treaty of Lausanne. In the Treaty, the non-Muslim population was the sole group that was defined as minorities (Minority Rights Group International, 2007).

It is therefore impossible to find reliable data and estimations of the Roma population in Turkey. However, the International Helsinki Federation for Human Rights (2006) reports that there are over 500,000 Roma people living throughout Turkey, while the Minority Rights Group International (2007) unofficially estimates that there are about two million. Most are sedentary and live in larger cities and towns but there are still some nomads who follow pre-established routes across the country. Roma people generally tend to subscribe to Islam, but there are also a few Christian Roma people as well (International Helsinki Federation for Human Rights, 2006). Education levels tend to be low. Illiteracy, for example, is a widespread feature and participation in secondary school and higher education are lower than for the majority group (Minority Rights Group International, 2009). Roma tend to be poor, and typically take up low paid and low skilled employment (Kolukirik and Toktas, 2007). The majority of the population commonly regard Roma unfavorably and view them as involved in the perpetration of crime (Kolukirik and Toktas, 2007). 
According to the European Roma Rights Center (ERRC), Roma routinely experience acute social exclusion, amounting to the violation of their economic, social and cultural rights, and they have difficulty accessing personal documents, which in turn affects their ability to access social welfare, medical care, and legal marriage.

\section{Aims of the present study}

The present study focused on civic and political engagement among young Turks and Roma people. In particular, we explored their understanding of citizenship; their perceptions about young people's participation; their sources of information and knowledge; their personal and group experiences of participation; and their proposals for promoting inclusion and civic and political participation. Our main goal was to identify the factors and processes which are responsible for civic and political engagement and participation among young Turks and Roma people. Our main reasons for addressing and assessing the situation of Roma people in Turkey were because national censuses do not take into account people's ethnic origins and because the definition of what constitutes a "minority" is contested (Kaya and Baldwin, 2004), with Roma people having a unique position in this regard. No differentiating factor such as a country of origin is present because they have been living in the "host" country for such a long time. Although each individual formally enjoys equal legal, socio-economic and political rights, there are no special rights or obligations conferred upon particular social, class, religious or ethnic groups in Turkey (Barry, 2001), and it was anticipated that factors such as low educational level, lack of opportunities and resources, social discrimination and unemployment would affect Roma participants' perceptions and patterns of civic and political engagement.

\section{Method}

\section{Participants}

Eight focus groups were conducted with young Turks and Roma participants. Different groups were conducted depending on participants' gender and ages (16-18 year olds vs. 20-26 year olds). These two age groups were chosen on the basis of previous research suggesting that people of this age are often excluded from the political process and in some countries are exhibiting increasing levels of political apathy. Altogether 8 focus groups were realized with 55 participants (28 males, 27 
females), the details of which are shown in Table 1.

Table 1. Distribution of the Focus Groups Participants by Age, Gender and Minority/Immigration Category

\begin{tabular}{|l||l||l||l|}
\hline Participants & Roma & Turk & Total \\
\hline \hline Female (16-18) & 8 & 7 & 15 \\
\hline \hline Female (20-26) & 6 & 6 & 12 \\
\hline Male (16-18) & 7 & 8 & 15 \\
\hline Male (20-26) & 7 & 6 & 13 \\
\hline \hline Total & 28 & 27 & 55 \\
\hline \hline
\end{tabular}

In the process of composing the groups, the research team attempted to recruit participants having different characteristics in terms of their socio-economic and educational status, as well as their levels of civic and political participation. Although with regard to their socio-economic status and educational backgrounds the participants were diverse, the young Roma typically experienced poorer living conditions and had lower educational status. All of the younger Turks were students attending secondary education. Participants aged between 20 and 26 years old were more heterogeneous in terms of their educational and occupational statuses, but none of the Roma participants were university students. Instead, reflecting the general status of the Roma population in Turkey, they were either unemployed or working in temporary jobs.

The Roma individuals included in the focus groups were recruited through their local community organizations and organizational networks, while the Turks were recruited from different secondary schools and universities through snowball sampling. In recruiting the Roma participants, moderators communicated with Salihli Municipality (an administrative district within Manisa) as it was known that there was a large population of Roma people living there. The participants were then recruited with the help of a Roma person who worked for the municipality. For the younger Turkish participants, a school counselor for one of the central high schools in Ankara 
was contacted. The older Turkish participants were recruited from the personal contacts of members of the research team.

\section{Procedure}

The Roma focus groups were conducted in places that the municipality arranged for the research team; the younger Turkish focus groups were conducted in the school library; and the older Turkish focus groups took place at Ankara University.

The facilitators used a focus group topic guide. This covered the participants' understanding of citizenship, perceptions of young people's participation, sources of information and knowledge, personal and group experiences of participation, and proposals for promoting inclusion and civic and political participation. The focus group facilitator and reporter, who worked for the researchers, were young Turks.

Focus group discussions were tape-recorded. Prior to data collection, every participant in the focus groups signed an informed consent form. Some pictures relating to civic engagement and participation activities were used as an icebreaker at the beginning of each focus group. There was no time limit set on the duration of discussions, but none of them lasted for longer than 90 minutes.

\section{Analysis}

Thematic content analysis method was used to analyze the data. After transcribing verbatim the focus group discussions, themes were decided revolving around the five major topics of participants' understanding of citizenship, perceptions about young people's participation, sources of information and knowledge, personal and group experiences, and proposals to promote inclusion and (civic and political) participation. The themes emerged following a theory-guided analysis focusing on young people's civic engagement.

\section{Results}

\section{Participants' understanding of citizenship}

The most striking finding of the study in relation to participants' understanding of citizenship was that alongside nationality and rights and obligations, 
participants (especially the Roma, but also some Turks) tended to refer to social inequalities and income levels in relation to citizenship. The Roma participants especially associated poverty and unemployment with second class citizenship:

"You can expect anything from a man if he is unemployed and does not have money"

(Roma 20-26, male)

Participants also referred to cultural discrimination and negative prejudice as important impediments to being a full citizen. The difference between the groups was in their understanding of discrimination. Although Roma participants had a tendency to locate the discrimination in government policies and society itself, the young Turkish groups emphasized education and personal effort. They believed the government had to do a lot for better citizenship but they also believed in personal capacity and the need to strive for better citizenship. While Roma participants referred to cultural discrimination and negative prejudice as important impediments to being a full citizen, participants from the Turkish group emphasized the self-potential of citizens:

"State is responsible from many things but the people are capable to be active in achieving better life and better society"

(Turk 16-18, male)

Furthermore, almost all participants claimed that they did not have enough information about their rights and obligations as citizens. In general, the perceptions of participants were firstly related to the duties of citizenship such as paying taxes and doing military service. Relating to military service, one participant from the older female Roma group stated that they faced discrimination and people looked at Roma in rather a negative way as if they were "untouchables" and said:

"People think we are close to Kurds, but they are terrorists... our sons fulfil their military service".

(Roma 20-26, female) 
This ethnic tension was considered to be the most important factor by many Roma people, and was seen as locating Roma in another category which led to the consideration of these people as second-class citizens.

As an important index of citizenship, participants were asked about their perceptions of environmental and human rights issues in their society. None of the participants seemed interested in environmental issues that much. Global warming was mentioned as the main important problem of the world concerning the environment in some of the participants in the older Turk groups, but not in the Roma groups.

On the other hand, human rights issues were discussed in the light of discrimination. The Roma participants especially mentioned what the issues of citizenship and human rights meant for themselves, and the discrimination to which they were exposed. All of the participants agreed that people saw Roma as secondclass citizens and although Roma people were showing all due respect to the state and institutions, they were still treated as outsiders. They mentioned that the high rate of unemployment among Roma youth can be understood in the light of the discrimination:

"If there was no unemployment, people would not chose to be malevolent... nobody wants this but the circumstances push people"

(Roma 20-26, male).

\section{Participants' perceptions of young people's participation}

Two important elements that were prominent in the focus group discussions in terms of participants' perceptions of young people's participation were the barriers/disincentives against participation and images about young people's participation. Participants mentioned various barriers against civic and political participation including:

Being labeled as a proponent of a particular ideology and/or political party (both younger and older participants)

- $\quad$ Difficulties of finding jobs in the case of being labeled (younger participants) 
- $\quad$ Loss of job (older participants)

- $\quad$ The need to pass the university exam (younger participants)

- $\quad$ Early marriage (female, Roma participants)

- $\quad$ Lack of efficacy (older participants)

An important finding of the study is the dominance of negative images among the participants about young people's participation. Thus, most of the participants thought that different ideological groups and/or leaders disparage young people who are politically active. They also tended to conceive politically active young people as 'careless' in terms of earning their means of living. Furthermore, participants aged between 20 and 26 years were more cautious with respect to civic and political participation in that they tended to condemn different forms of action and protest, such as marches, demonstrations and graffiti in stronger terms. They tended to regard them as deviant behaviors and they also emphasized their ineffectiveness and inconvenience:

\section{"Making violent demonstrations and drawing graffiti are not proper means and they are generally inefficient"}

(Turk 20-26, male)

The Roma participants especially were not in favor of alternative forms of protest such as chaining oneself to a building, which is regarded as a symbol against injustice and inequality, as these are disrespectful to legal procedures and institutions. Participants even generalized their belief to all Roma people. They believed that alternative forms of expression were not suitable for them.

“These forms do not fit us" (Roma 20-26, male)

"Alternative and radical forms may be harmful to both protesters themselves and other people" (Roma 16-18, male)

For the Turkish group, the participants thought alternative forms of participation were important because of their impact on the visibility and popularity of the case defended. When the participants were asked about their participation through 
media, the internet especially was mentioned as a way to express their views by Turks. Roma people probably have less access to the internet and therefore do not use this medium to participate.

Unemployment and poverty emerged as the most prominent issues that served as impediments to male Roma participants' civic and political engagement, involvement and participation. During the focus groups, they tended to associate almost every question with these two problems and with lack of access to what they needed. They tended to condemn different forms of action and protest to express their problems. This therefore ruled out using collective action against issues such as unemployment. They implied that unemployment pushed them to the extreme:

"Should we revolt against the state for being listened to?"

(Roma 20-26, male)

Recalling the tendency of Roma people to distrust alternative forms of participation, this statement was related to questioning the system. As they mentioned that they valued "staying loyal to the country" and were mostly not interested in politics, especially the males, they tried to find ways to fulfill their basic needs:

"They think we are thieves. A Roma only steals when he is hungry today. He never thinks about stealing more for tomorrow." (Roma 20-26, male)

On the other hand, an interesting pattern was found for the female Roma participants. Early marriage and poverty constituted their main impediments. Some of them stated that they had left school for work and for their parents' expectation to get married. It was not possible for them to engage in civil political participation before things had worked out as expected by their family members:

"Some families prefer not to send their girls to the school, as they do not believe in the education of girls" (Roma 16-18, female)

"I have to find a job, or expect my husband to have a sufficient income enough for the education of our future children. It is hard for Romas to find such kind of 
decent job" (Roma 16-18, female)

Among the Turkish groups, the participants belonging to the 16-18 year old age group listed the university entrance exam, lack of economic independence, parents' prohibitive attitudes, and the existence of hostile police intervention to those who engage in demonstrations, as among the important disincentives against young people's participation. The participants belonging to the 20-26 year old age group emphasised, alongside the same considerations (except for the university entrance examination), a lack of political efficacy.

Opinions about parents' prohibiting attitudes were differentiated among the groups. While the Turkish group pointed out parental factors as a barrier to their engagement, interestingly Roma people did not mention it as much but mentioned other social factors instead. Younger Turkish participants especially stated that they did not have the economic independence which would enable them to engage in civilpolitical activity. Another participant mentioned the age issue from another perspective, claiming that their views on political issues were determined to a great extent by the opinions and attitudes of their parents. She said:

"We are at high school, how can we do such kind of thing?... We are dependent on our families."

(Turk 16-18, female).

This was something which had to be accepted according to the participant and could be overcome in later years. Another participant underlined the everyday life problems of young people. She claimed that it was hard for people to allocate time and resources given the hard work that many have to do and the care that they should give to family members. While lack of time was an issue for the young Turkish people because of educational requirements, for most of the Roma participants, marriage and early parenthood were more widespread concerns.

\section{Sources of information and knowledge}

For almost all participants, regardless of the groups to which they belonged, the most important sources of influence were family members (especially fathers) and 
the peer group. Family elders were also frequently cited. One particular difference between the younger and older participants was that while younger participants thought that their parents sometimes excluded them when they talked about social and political issues, older participants preferred to benefit from their parent's views. One participant from the Roma group argued that above a certain age their influence had declined and he was capable of shaping his own opinion in a particular issue. Another said:

"I listen my mother and try to benefit from her experience"

(Roma 16-18, female)

Similarly, one participant from the Turkish group stated that she shared her opinions with her older brother and claimed that her parents were not sophisticated in discussing politics. In addition, participants tended to hold similar beliefs and attitudes as their family with regard to political and social issues. However, some from the male Turkish group aged 16-18 stated they always fought with their fathers in their thinking and fathers were never seen as influential:

"My parents exclude me while they talk" (Turk 16-18, male)

The media (particularly visual media rather than printed) and the internet were also cited as influential sources of information. Turkish participants mentioned that the large-scale media tools such as big newspapers and private channels transformed or even corrupted the news so they did not believe them in general. Roma participants in general were an exception in this regard. Thus, although they expressed that they generally spent large amounts of time in front of the TV, they did not for the most part follow the news or TV programs on civic and political issues. These individuals also had no or restricted access to the internet.

\section{Personal and group experiences}

Participation experiences reported by the participants included:

- Creating blogs on the internet where people could discuss social and political issues

- $\quad$ Taking part in internet discussion forums 
- Sharing videos and messages on social and political issues on Facebook

- Participating in the so-called 'republican march' which had the aim of protecting secularism

- Writing petitions to local authorities concerning neighborhood related issues

- Participating in boycott campaigns

- Participating in a commemorative ceremony (of Hrant Dink, an intellectual of Armenian origin who was murdered in 2007)

- Participating in activities concerning Bulgarian Turk music and folklore

Although participants generally thought that civic and political participation was important for being a member of a society, they expressed that personally they had restricted participation. The younger male Turkish participants appeared to have the highest levels of participation.

An important finding of the study was that, on the one hand, older participants felt themselves too 'old' to participate, that is, they thought that it was too late for them to participate due to the need to have a secure and stable life. On the other hand, younger participants felt themselves too 'young' to participate by emphasizing the need to find jobs, to earn a living and 'to stand on one's own legs', etc.

Turkish participants stated that to engage in civil-political issues requires time and resources. They also referred to involvement in a political activity as being an undesirable thing in society. Regarding this, one participant stated that he was planning to start a project but it was too soon to talk about it and he had to find ways to prevent this project from turning into a political one. While older Turkish participants mostly stated that participation was something that they had done while they were in university, younger participants mentioned their lack of knowledge and time to participate in a cause because they were still at high school.

In complete contrast, all Roma participants mentioned that they did not have any personal experiences of civil-political participation. They explicitly stated that they were not members of any group or association. One clearly stated that they did not participate because of the ineffectiveness of participation in civil-political issues. 
Another argued that they were a rather mild people, trying to sort things out in a nice way, and marches, protesting against authority and other such kind of activities did not fit their taste and understanding.

Welfare and the well-being of people was also important in this group:

"If we had more opportunities and resources we would have the motivation to participate” (Roma 20-26, male)

Seeing participation as a useless effort, and the idea that "nothing will change", was explicit in all groups. One Turkish participant aged 20-26 believed that demonstrations were not effective and disturbed many people:

"There should be another way for protest"

"Violence used by police is a big demotivator"

(Turk 20-26, male)

Another participant from this group voiced her distrust of the organisers of protests (implying trade unions and political parties). The difference between the groups was not in their negative perceptions of the effectiveness of participation but the reasons they gave as underlying factors for not participating. While Turks pointed out factors such as their age, parent's attitudes, lack of time or the bad reaction they face when they participate in a political cause, Roma people mostly emphasized the lack of sources of information and financial difficulties.

Furthermore, the participants had little or no perceptions of or ideas about the European dimension of civic and political participation, regardless of their migrant/minority status, age and gender.

\section{Proposals to promote inclusion and (civic and political) participation}

On the one hand it was proposed by the participants that young people should be informed in terms of their rights and obligations and they should be encouraged to discuss political issues in the process of education. On the other hand, they expressed the view that youth participation cannot be an issue to be dealt with on its own, since 
it is related to other macro processes. Some of the participants, for instance, said that it was better to decrease unemployment than give information to young people about their rights and obligations.

Among the proposals to promote inclusion and participation, the following were suggested:

- To reform the education system in line with the aim of promoting civic and political participation.

- To allocate more resources and increase financial support to projects which could be helpful in increasing the level of participation.

- To generate new mechanisms by the authorities to learn about the feelings and opinions of young people.

- To make the police more tolerant in order to promote inclusion in political participation.

Almost all of the Roma participants, again, saw unemployment as an issue. They stated that the level of unemployment should be decreased so that people could be more interested in civil-political issues:

“Job, job, job” (Roma 20-26, male)

Better education and more employment opportunities could make a drastic difference according to them. As a proposal, one participant aged 16-18 years stated that the state should lower taxes and promote private investment.

Female Roma participants, again, emphasized early marriage. It was seen as the only path to be followed by them. To have the responsibility of a family at an early age meant that they would not be interested in further education or any other issues. One participant also suggested that the state should support those families with financial difficulties and provide the necessary means so that girls could have as much education as boys:

"The age for marriage in our neighborhood is around 15 and it made impossible for young people to engage in civil political issues once they began to hold responsibility for their families and children" (Roma 20-26, female) 
Although it was asked directly, Turkish participants did not offer proposals for the inclusion of groups that were relatively excluded, but preferred to make general statements about the promotion of participation in general and the participation of young people in particular. In this respect, young Turkish people viewed the subject only through their own life context, and lacked any exposure to discrimination in the way that Roma people experience.

\section{Discussion}

In the Introduction, it was noted how Flanagan and Faison (2001) describe the concept of civic engagement. A person who belongs to a community is also a member of the polity. Civic engagement requires the individual to meet the responsibilities and to fulfill the duties of this particular polity. However, youth learn what it means to be a citizen through their everyday experiences of membership in their communities and the opportunities which they have to exercise rights and fulfill obligations. And when ethnic minorities feel excluded from the polity, they are also less likely to feel obligated to that polity (Wray-Lake, Syvertsen and Flanagan, 2008). At this point, young people in general, and especially those with different ethnic backgrounds, need to be taken into account to understand the factors that might be related to levels of engagement. Accordingly, we included Roma people when we designed our study. Although the socio-economic conditions of Roma are under-researched, it is clear that Roma are particularly exposed to high rates of poverty and unemployment and are largely operating in the informal economy. A recent EU-wide public opinion survey shows that a quarter of Europeans would feel uncomfortable to have a Roma as their neighbor. In some countries, half of the respondents take this view (Eurobarometer, 2008).

Turkish attitudes and laws on minorities have progressed considerably over the past decade, but many reforms are needed if the country's legal framework and practice are to reach international standards. Addressing the needs of Roma communities as well as other ethnic groups is critically important for maintaining social cohesion in Turkey. Much of the responsibility for addressing these challenges lies at national, regional and local levels. 
The findings which have been described in this paper show that Roma and Turkish male and female youth at two different ages (16-18 and 20-26) have different tendencies and attitudes concerning civic and political engagement. Each sub-group has its specificities in terms of their understandings of citizenship, perceptions about young people's participation, their sources of information and knowledge about civic and political issues and their personal and group experiences of participation. Regardless of category, almost all young people included in the study expressed that they do not have enough information about their rights and obligations as citizens and there are different barriers against their political involvement and participation. All major topics that were addressed by the study highlight important drawbacks in relation to youth civic and political participation in Turkey.

Since the study included young people from different age ranges, it was expected that it would reveal differentiation between the groups. The most engaged and active group in general was the Turkish male group participants aged 16-18. As previously emphasized, age was taken into consideration during the discussions with all Turkish participants. However, because of the small sample size and the qualitative nature of our study, we do not wish to speculate widely on the gender differences apparent in our sample. Gender was only the issue among female Roma participants because of early marriage.

A significant finding relates to the participants' understanding of engagement related concepts. Since Roma people emphasized the unemployment problem to address almost every issue, we believe that Roma youth see economic participation as being more important than other types of activities such as political participation. It is our belief that the Roma participants defined "participation success" as being in employment in this context and focused on their daily life experiences. They are married and have left school already so they need to find a job to fulfil their basic needs and when they cannot solve this problem, they have their ethnicity to blame. In contrast, most Turkish participants were mostly interested in some social issue but they complained about their age or their lack of time and information. At this point, they preferred to remain silent for the "right time" to come or were simply not interested in being a part of any kind of community. 
However, research shows that a strong identification with one's ethnic identity can lead to the development of an alternative culture that perpetuates feelings of exclusion (Brewer, Von Hipple and Gooden, 1999; Gaertner, Dovidio, Nier, Ward and Banker, 1999). Our findings draw attention to the connection between the life contexts of particular ethnic groups and their civic engagement. Although we take ethnicity as moderator factor that might lead to disengagement, our findings also show that context matters, as do age, gender and ethnic background. If Roma people face discrimination, the reason for their low level of engagement is not due to different regulations. Perhaps the path that should be followed is determining the disengaged group in terms of their life condition first and then helping them to create an environment in which they can increase their own engagement. We need to have a wider perspective in order to understand how to have an influence on these individuals' lives. We hope that further quantitative research will be realized to improve our knowledge about these issues by enabling us to reach a more detailed and multifaceted analysis. 


\section{References}

Adaman, F. and Keyder, Ç. (2006) "Poverty and Social Exclusion in the Slum Areas of Large Cities in Turkey", Retrieved April 26, 2012 http://ec.europa.eu/employment_social/social_inclusion/docs/2006/study_turk ey_en.pdf.

Barnes, S. H., Kaase M. (1979). Political action: Mass participation in five Western democracies. Beverly Hills and London: Sage Publication.

Barry, B. (2001). Culture and Equality: An Egalitarian Critique of Multiculturalism. Oxford: Polity Press.

Brewer M.B., von Hipple W. and Gooden M.P. (1999). Diversity and organizational identity: The problem of entrée after entry. In D.A. Prentice\& D.T. Miller (Eds.) Cultural Divides. New York: Russell Sage.

Community Instruments and Policies for Roma Inclusion, Com (2008). Retrieved August 3, 2011 http://ec.europa.eu/social/BlobServlet?docId=1585\&langId=en

De Piccoli, N., Colombo, M. and Mosso, C. (2002) Active Participation as an Expression of the Sense of Community, paper presented at the IV European Congress of Community Psychology, Barcelona, Spain, 8-11 November.

Flanagan , C. A. and Faison, N. (2001). Youth civic development: Implications of research for social policy and programs. Social Policy Report, Vol. XV (1). Ann Arbor, MI: Society for Research in Child Development.

Flanagan, C., and Sherrod, L. (1998). Youth political development: An introduction. Journal of Social Issues, 54 (3), 447 - 456.

Gaertner S. L., Dovidio J. W., Nier, J. A., Ward C.M., and Banker B.S. (1999). Across cultural divides: The value of a superordinate identity. In D.A. Prentice\& D.T. Miller (Eds.) Cultural Divides. New York: Russell Sage.

Galston, W.A. (2001). Political knowledge, political engagement, and civic education. Annual Review of Political Science, 4, 217 - 234.

IEA Civic Education Study: Citizenship and Education in Twenty-eight Countries Report. (1999).

International Helsinki Federation for Human Rights (2006), Turkey: A Minority 
Policy of Systemic Negation, Report prepared by the International Helsinki Federation for Human Rights, October 2006.

Kaya, N., Baldwin, C. (2004). Minorities in Turkey: Submission to the European Union and the government of Turkey. Retrieved April 26, 2012 www.minorityrights.org/download.php?id=183

Kolukirik S. and S. Toktas (2007), Turkey's Roma: Political Participation and Organization. Middle Eastern Studies, vo.43, no.5, pp. 761-777.

Menezes, I. (2003). Participation Experiences and Civic Concepts, Attitudes and Engagement: implications for citizenship education projects. European Educational Research Journal. Vol. 2; 3 pp 430-445.

Minority Rights Group International (2007), A Quest for Equality: Minorities in Turkey, Report prepared by Minority Rights International.

Putnam, R. D. (1993). Making Democracy Work: civic traditions in modern Italy. Princeton, NJ: Princeton University Press.

Sherrod, L. (2007). Civic Engagement as an Expression of Positive Youth development. In eds. Rainer K. Silbereisen and Richard M. Lerner. Approaches to Positive Youth Development. Sage Publications.

Skocpol, T. (2003). Diminished Democracy. From Membership to Management in American Civic Life. Norman: University of Oklahoma Press.

Skocpol, T. and Fiorina, M.P. (1999) Civic Engagement in American Society. Brookings Institution Press. pp.1-27.

Stewart, E. and Weinstein, R.S. (1997). Volunteer Participation in Context motivations and political efficacy wthin three AIDS organizations. American Journal of Community Psychology, 25, pp. 809-837.

Turkish Statistical Institute. (2010) Retrieved April 26, 2012. http://www.turkstat.gov.tr/PreTablo.do?tb_id=37\&ust_id=11

UNDP. (2008). “Human Development Report - Turkey 2008: Youth in Turkey”. Ankara.

Watts, R. J. and Flanagan, C. (2007). Pushing the envelope on youth civic engagement: A developmental and liberation psychology perspective. Journal of Community Psychology, 35:6, pp.779-792. Published online in Wiley InterScience.

Wray-Lake, L., Syvertsen, A.B. and Flanagan, C. (2008). Contested citizenship and 
social exclusion: Adolescent Arab-American Immigrants' views of the social contract. Applied Developmental Science, 12, 84-92.

Zimmerman, M. A. (1995). Psychological Empowerment: issues and illustrations, American Journal of Community Psychology, 23, pp. 581-599. 